\title{
Effects of Job Burnout on Employees Satisfaction in Selected Health Service Sector in Southwestern Nigeria
}

\author{
Kehinde Adebola Adewa*, Ayodeji Akinlolu Agboola \\ Department of Management and Accounting, Obafemi Awolowo University, Ile Ife, Nigeria \\ Email: *kadewa@oauife.edu.ng, agboolaaa@yahoo.com
}

How to cite this paper: Adewa, K.A. and Agboola, A.A. (2020) Effects of Job Burnout on Employees Satisfaction in Selected Health Service Sector in Southwestern Nigeria. Open Journal of Applied Sciences, 10, 877-890.

https://doi.org/10.4236/ojapps.2020.1012062

Received: December 1, 2020

Accepted: December 27, 2020

Published: December 30, 2020

Copyright $\odot 2020$ by author(s) and Scientific Research Publishing Inc. This work is licensed under the Creative Commons Attribution International License (CC BY 4.0).

http://creativecommons.org/licenses/by/4.0/

\begin{abstract}
This paper examined the effects of job burnout on job satisfaction among selected health service employees in Southwestern Nigeria. The issue of job burnout has been researched, with limited attention to the health service employees in Southwestern Nigeria. The state of health of the people is vital to the survival of any economy as well as the development of any Nation. Data were obtained from the administration of questionnaires to 400 employees who were Doctors, Nurses, Pharmacists \& Administrators with permanent employees' status. Multiple regression was used to analyze the data. Major causes of burnout discovered include emotional exhaustion, depersonalisation while personal achievement increases employee job satisfaction. Results of the study showed that insufficient motivation, low organisational support and high job demand could lead to job burnout. The study revealed an inverse relationship between job burnout and employee satisfaction which makes them to perform below expectations. The study concluded that since job burnout inhibits performance and manifests significantly in their service delivery, employers should put policies in place to mitigate it.
\end{abstract}

\section{Keywords}

Job Burnout, Emotional Exhaustion, Depersonalisation, Personal Accomplishment, Employees Satisfaction

\section{Introduction}

Effective performance of employees is critical to the growth and development of any nation. The state of wellness and soundness in body determines the extent to which individuals can meaningfully contribute to nation building [1] Ubochi, Ehwarieme, Anarado and Oyibocha (2019). The human desire to be in the right 
and good health conditions is important to individuals and society at large. It is often seen as crucial, because the economy of the nation depends on the well being of her citizenry as well as its employees. Employees need to be mentally stable and physically fit to function well and impact the socio-economic life of a nation. This condition is required both in the tangible and intangible sectors of the economy.

For the growth and development of any Nation, effective performance of its employee is critical especially that of the health service employees, because they deal directly with life. The employees are expected to be physically and mentally fit before they can perform effectively. Their effective performance is revealed by finding a self-fulfilment in their work environment, organisational support, motivation and several features of the job that can stimulate employee satisfaction.

Health sector constitutes an important sector of the economy which requires tactical management of their human resources. The management of human resources is determinants of the attainment of organisational goal; in most cases, the numerical strength of health service employee is grossly inadequate to meet up with client's expectations, job demand and accessibility [2], Tsai, Jones, Klee and Deegan (2020), where insufficient motivation, low organisation support and high job demand often leads to job burnout.

Job burnout is identified as reaction to emotional exhaustion, depersonalisation, reduction in personal accomplishment that arises from the workplace [3] Elham (2019); [4] Bazmi et al. (2019). Review of literature also revealed that in practice, problems faced by employees within the workplace are stress, depression, apprehension, lack of support and lack of job description among others which are identified to be sensitive components that influences employee's satisfaction [5] Luna-Arocas and Camps (2008). Also, most of the empirical studies conducted were centred on either burnout, work stress, intention to quit and work family separately [6] Karabay, Tezergil, and Kose (2014); [7] Maslach et al. (1981).

However, the limitations associated with health service employees in Southwestern Nigeria in term of job burnout have not been adequately established empirically. The question that will be addressed consequently upon review of literature is to: examine the effects of job burnout on employee's satisfaction among selected health service employees in Southwestern Nigeria.

\section{Literature Review}

Job burnout was classified into a three-dimension that comprises emotional exhaustion, depersonalization and reduced personal accomplishment, which are associated with the sense of being used up as a result of enduring exposure to work pressure thereby leading to the workers spacing themselves from client, becoming cynical and disconnected while also having a mindset of ineffectiveness within the place of work despite the level of committed effort. It is that syndrome that is affecting the exhausted employee, the overworked who initially 
were once engaged and motivated [7] Maslash and Jackson, (1981).

Therefore, how an employee can sufficiently reduce its burnout and increases employee satisfaction may largely depend on the attention of its management to the issue of burnout, which can largely mitigate these effects [8] Wright and Bonett, 1997; [9] Meyer, Stanly, Herscovitch and Topolnytsky 2002; [10] Franke and Park, 2006. These effects can be reduced with attendant increase in employee satisfaction by making timely managerial decisions, sufficient motivation, organisational support and low job demand [11] Riggle, Edmondson \& Hansen, 2009; [12] Koster, Grip and Fouarge, 2011.

Studies have argued the implications of job burnout among employee's [13] Wafaa 2019; [14] Sugumaran, Ahdullah, and Manaf 2016; [6] Karabay, Tezergil, and Kose 2014; [15] Lizano, 2015. Also, empirical findings on job burnout and its level on employees have been explored by researchers [2] Tsai, Jones, Klee \& Deegan, 2020; [16] Al-Adwan and Al-Khayat, 2017; [17] Swartz and Potgieter, 2017. Many of these studies focused on job burnout in different sectors while isolating health service employee in southwest, Nigeria. Also, another set of empirical investigation focused on existence and factors that drive job burnout [18] Adebayo, Segun-Adeniran, Fagbohun, and Osayande 2018. The focus of job burnout tends toward non service industry, perhaps, is due to the fact that their effects are easily quantifiable and that the impacts are more noticeable on their profitability.

However, there have been limited evidence concerning the extent to which job burnout affects job satisfaction among selected health service employee in southwestern, Nigeria. Thus, what has not been considered in previous studies is the cumulative effects of job burnout on employee satisfaction among selected health service employees in the southwestern region given their sensitivity to livelihood, it is important to ascertain the effects.

Based on this foregoing, the study extended the frontier of knowledge by exploring empirically, i. the effects of job burnout on employee satisfaction among selected health service employee in southwestern, Nigeria.

\section{Hypothesis of the Study}

Ho: job burnout does not influence employee's satisfaction.

$\mathrm{H}_{1}$ : job burnout has influence on employee's satisfaction.

\section{Research Methodology}

The study area is Osun state, Southwestern Nigeria. The surrounding of the state is North by Kwara state; south by Ogun state; east by Ekiti and Ondo states; and west by Oyo state. Osun state has 30 Local Government Areas and has the coverage of approximately $14,875 \mathrm{sq}$. $\mathrm{km}$. on longitude $4^{\circ} \mathrm{E}$ and $5^{\circ} \mathrm{E}$ and latitude $5^{\circ} \mathrm{N}$ and $8^{\circ} \mathrm{N}$ with estimated population of $4,137,627$ million people spread across six main zones Osogbo, Ede, Iwo, Ikirun, Ilesha and Ile-Ife [19] NPC, 2006 . 
The study employed a multi-stage sampling procedure. The first stage was a purposive selection of (Ife - Ilesa - Eleyele). At the second stage, selection was based on the health service sector that has highest number of experts, three (3) Local Government Areas (LGAs) were selected that have hospital managed by the federal government which were: Obafemi Awolowo University Teaching Hospital (OAUTHC), OAUTHC Westly Guild, OAUTHC Urban Comprehensive Hospital Unit. The third stage involved stratification of the hospitals in each local government into four groups of Doctors, Nurses, Pharmacists and Administrators. The final stage was a snowball sampling of 35 respondents from each group of (Doctors, Nurses, Pharmacists and Administrators) in the three LGAs. A total number of four hundred and twenty (420) health service employees were therefore interviewed. However, only four hundred (400) samples were found analysable due to incomplete responses.

A well-structured questionnaires and personal interview were conducted, primary data were collected from the respondents. Socioeconomic characteristics such as gender, age, marital status, service years, level of education, job burnout and employee job satisfaction were elicited. Descriptive statistics, factorization and OLS regression model were then used for analysis. Descriptive statistics including frequency counts, weighted mean score, standard deviation and percentage were used to describe the socio-economic characteristics and profile perception of health service employees about job burnout. The data were analysed with SPSS package version 21 and Stata package version13.

\section{Statistical Model Specification}

The OLS regression is specified explicitly as:

$$
\mathrm{EST}=\beta_{0}+\beta_{1 i} \mathrm{EEH}+\beta_{2 i} \mathrm{PEA}+\beta_{3 i} \mathrm{DPE}+e_{i} \cdots
$$

where:

$$
\begin{array}{ll}
\text { EST } & \text { Employee satisfaction (Likert scale) } \\
\text { EEH } & \text { Emotional Exhaustion (Likert scale) } \\
\text { PEA } & \text { Personal Achievement (Likert scale) } \\
\text { DPE } & \text { Depersonalization (Likert scale) } \\
e_{i} & \text { disturbance terms }
\end{array}
$$

$\beta_{0}$, is the constant, $\beta_{1 i} \beta_{2 i} \beta_{3 i}$ are parameters of factor score and items used to capture Emotional Exhaustion (number) and Personal Achievement and Depersonalization respectively.

\section{Results and Discussion}

\subsection{Demographic Characteristics of Respondents}

The result in Table 1 shows the personal characteristics of employees in the $\mathrm{Ni}$ gerian Health sector. Gender distribution reveals that $42 \%$ were male and 52\% were female. The implication is that Nigerian health sector is not gender bias. The study thus covers both the male and female gender opinion of job burnout 
impact on the works' satisfaction. Age distribution shows that about $41 \%$ of the respondents aged between 20 - 39 years while $57 \%$ fell between 40 - 59 years old. These respondents obtained first degree in B.Sc. (29.7\%); HND (19.5\%) and Post graduate (34.5\%). Most of the respondents (30.5\%) spent between $1-5$ years in service, some other spent 6 - 10 years of experience (34.3\%) while $19.5 \%$ and 9.2\% respectively spent between $11-15$ years and $16-20$ years in service. The distribution of respondents by specialty shows that respondents specialized in disciple that are directly and indirectly linked with job burnout. These were Medical Doctor (21\%), Pharmacists (17\%), Nurses (18\%), and Administrators $(43 \%)$.

Table 1. Demographic characteristics of respondents.

\begin{tabular}{|c|c|c|}
\hline Variable & Frequency & Percentage (\%) \\
\hline \multicolumn{3}{|l|}{ Gender } \\
\hline Male & 189 & 47.3 \\
\hline Female & 211 & 52.7 \\
\hline \multicolumn{3}{|l|}{ Age (years) } \\
\hline $20-39$ & 165 & 41.2 \\
\hline $40-59$ & 229 & 57.3 \\
\hline 60 years and above & 6 & 1.5 \\
\hline \multicolumn{3}{|l|}{ Academic Qualification } \\
\hline HND & 78 & 19.5 \\
\hline B.Sc. & 119 & 29.7 \\
\hline Post Graduate & 138 & 34.5 \\
\hline Others & 65 & 16.3 \\
\hline \multicolumn{3}{|l|}{ Years of Service } \\
\hline $1-5$ & 122 & 30.5 \\
\hline $6-10$ & 137 & 34.3 \\
\hline $11-15$ & 78 & 19.5 \\
\hline $16-20$ & 37 & 9.2 \\
\hline $21-30$ & 26 & 6.5 \\
\hline \multicolumn{3}{|l|}{ Specialty } \\
\hline Doctor & 86 & 21.5 \\
\hline Pharmacist & 68 & 17.0 \\
\hline Nurses & 72 & 18.0 \\
\hline Administrator & 174 & 43.5 \\
\hline Total & 400 & 100.0 \\
\hline
\end{tabular}

Field survey, 2020. 


\subsection{Examining the Dimensions of Job Burnout}

Table 2 presented distributions of respondents on items constituting job burnout dimensions. The instrument was tested for internal reliability and degree of concordance. Cronbach's alpha which is supported by a relative theory of

Table 2. Table showing distribution of respondents' opinions on Dimensions of Job burnout.

\begin{tabular}{|c|c|c|c|c|c|c|c|c|c|}
\hline $\mathrm{S} / \mathrm{N}$ & Dimension: & SA & A & $\mathbf{N}$ & $\mathrm{D}$ & SD & WMS & Std. D & t-value \\
\hline A & Emotional Exhaustion & \multicolumn{8}{|c|}{ Cronbach alpha $=0.671$ and Kendall's W coefficient $=0.110^{*}$} \\
\hline 1 & I am emotionally disturbed by this work (A1) & $\begin{array}{l}67 \\
(16.7)\end{array}$ & $\begin{array}{l}64 \\
(16.0)\end{array}$ & $\begin{array}{l}49 \\
(12.2)\end{array}$ & $\begin{array}{l}108 \\
(27.0)\end{array}$ & $\begin{array}{l}112 \\
(28.0)\end{array}$ & $2.67^{\mathrm{da}}$ & 1.454 & $-4.609^{\star}$ \\
\hline 2 & $\begin{array}{l}\text { I feel scared occasionally when I get up in the } \\
\text { morning and have to face another day on my } \\
\text { job (A2) }\end{array}$ & $\begin{array}{l}46 \\
(11.5)\end{array}$ & $\begin{array}{l}74 \\
(18.5)\end{array}$ & $\begin{array}{l}42 \\
(10.5)\end{array}$ & $\begin{array}{l}115 \\
(28.8)\end{array}$ & $\begin{array}{l}123 \\
(30.8)\end{array}$ & $2.51^{\mathrm{da}}$ & 1.389 & $-7.019^{\star}$ \\
\hline 3 & I feel used up at the end of the workday (A3) & $\begin{array}{l}75 \\
(18.8)\end{array}$ & $\begin{array}{l}109 \\
(27.2)\end{array}$ & $\begin{array}{l}71 \\
(17.8)\end{array}$ & $\begin{array}{l}77 \\
(19.2)\end{array}$ & $\begin{array}{l}68 \\
(17.0)\end{array}$ & $3.12^{\mathrm{IN}}$ & 1.373 & 1.675 \\
\hline 4 & $\begin{array}{l}\text { Working with people directly put too much } \\
\text { pressure on me (A4) }\end{array}$ & $\begin{array}{l}56 \\
(14.0)\end{array}$ & $\begin{array}{l}45 \\
(11.2)\end{array}$ & $\begin{array}{l}46 \\
(11.5)\end{array}$ & $\begin{array}{l}95 \\
(23.8)\end{array}$ & $\begin{array}{l}158 \\
(39.5)\end{array}$ & $2.37^{\mathrm{da}}$ & 1.446 & $-8.781^{\star}$ \\
\hline 5 & $\begin{array}{l}\text { I find it easy to create a relaxed atmosphere and } \\
\text { condition with my patients (A5) }\end{array}$ & $\begin{array}{l}91 \\
(22.8)\end{array}$ & $\begin{array}{l}146 \\
(36.5)\end{array}$ & $\begin{array}{l}59 \\
(14.7)\end{array}$ & $\begin{array}{l}46 \\
(11.5)\end{array}$ & $\begin{array}{l}58 \\
(14.5)\end{array}$ & $3.42^{\mathrm{a}}$ & 1.342 & $6.183^{*}$ \\
\hline 6 & I personally feel energetic in my job (A6) & $\begin{array}{l}89 \\
(22.2)\end{array}$ & $\begin{array}{l}137 \\
(34.2)\end{array}$ & $\begin{array}{l}41 \\
(10.2)\end{array}$ & $\begin{array}{l}76 \\
(19.0)\end{array}$ & $\begin{array}{l}57 \\
(14.2)\end{array}$ & $3.31^{\mathrm{a}}$ & 1.378 & $4.535^{*}$ \\
\hline B & Personal Accomplishment & \multicolumn{8}{|c|}{ Cronbach alpha $=0.699$ and Kendall's W coefficient $=0.142^{*}$} \\
\hline 1 & $\begin{array}{l}\text { Working with people everyday trains me } \\
\text { (B1) }\end{array}$ & $\begin{array}{l}49 \\
(12.2)\end{array}$ & $\begin{array}{l}71 \\
(17.7)\end{array}$ & $\begin{array}{l}66 \\
(16.5)\end{array}$ & $\begin{array}{l}101 \\
(25.2)\end{array}$ & $\begin{array}{l}113 \\
(28.2)\end{array}$ & $2.61^{\mathrm{a}}$ & 1.378 & $-5.733^{\star}$ \\
\hline 2 & $\begin{array}{l}\text { I have positive feeling that my work with people is } \\
\text { influencing others' life (B2) }\end{array}$ & $\begin{array}{l}158 \\
(39.5)\end{array}$ & $\begin{array}{l}138 \\
(34.5)\end{array}$ & $\begin{array}{l}28 \\
(7.0)\end{array}$ & $\begin{array}{l}41 \\
(10.2)\end{array}$ & $\begin{array}{l}35 \\
(8.7)\end{array}$ & $3.86^{\mathrm{a}}$ & 1.283 & $13.366^{*}$ \\
\hline 3 & I feel I am working too hard on my job (B3) & $\begin{array}{l}78 \\
(19.5)\end{array}$ & $\begin{array}{l}123 \\
(30.7)\end{array}$ & $\begin{array}{l}51 \\
(12.7)\end{array}$ & $\begin{array}{l}100 \\
(25.0)\end{array}$ & $\begin{array}{l}48 \\
(12.0)\end{array}$ & $3.21^{\mathrm{a}}$ & 1.334 & $3.112^{*}$ \\
\hline 4 & $\begin{array}{l}\text { I feel I treat some recipients as if they were } \\
\text { impersonal object (B4) }\end{array}$ & $\begin{array}{l}75 \\
(18.7)\end{array}$ & $\begin{array}{l}47 \\
(11.7)\end{array}$ & $\begin{array}{l}54 \\
(13.5)\end{array}$ & $\begin{array}{l}92 \\
(23.0)\end{array}$ & $\begin{array}{l}132 \\
(33.0)\end{array}$ & $2.60^{\mathrm{da}}$ & 1.505 & $-5.282^{\star}$ \\
\hline 5 & $\begin{array}{l}\text { I do not really care what happens to some patients } \\
\text { (B5) }\end{array}$ & $\begin{array}{l}76 \\
(19.0)\end{array}$ & $\begin{array}{l}58 \\
(14.5)\end{array}$ & $\begin{array}{l}21 \\
(5.2)\end{array}$ & $\begin{array}{l}53 \\
(13.2)\end{array}$ & $\begin{array}{l}192 \\
(48.0)\end{array}$ & $2.43^{\mathrm{da}}$ & 1.625 & $-6.983^{*}$ \\
\hline 6 & $\begin{array}{l}\text { I have become more callous towards people since I } \\
\text { took my job (B6) }\end{array}$ & $\begin{array}{l}69 \\
(17.2)\end{array}$ & $\begin{array}{l}60 \\
(15.0)\end{array}$ & $\begin{array}{l}32 \\
(8.0)\end{array}$ & $\begin{array}{l}66 \\
(16.5)\end{array}$ & $\begin{array}{l}173 \\
43.25\end{array}$ & $2.47^{\mathrm{da}}$ & 1.567 & $-6.829^{*}$ \\
\hline 7 & $\begin{array}{l}\text { I calmly deal with emotional problems in my work } \\
\text { (B7) }\end{array}$ & $\begin{array}{l}126 \\
(31.5)\end{array}$ & $\begin{array}{l}161 \\
(40.2)\end{array}$ & $\begin{array}{l}32 \\
(8.0)\end{array}$ & $\begin{array}{l}40 \\
(10.0)\end{array}$ & $\begin{array}{l}41 \\
(10.2)\end{array}$ & $3.73^{\mathrm{a}}$ & 1.283 & $11.336^{*}$ \\
\hline $\mathrm{C}$ & Depersonalization & \multicolumn{8}{|c|}{ Cronbach alpha $=0.366$ and Kendall's W coefficient $=0.050^{*}$} \\
\hline 1 & I feel burned out from my job (C1) & $\begin{array}{l}92 \\
(23.0)\end{array}$ & $\begin{array}{l}97 \\
(24.2)\end{array}$ & $\begin{array}{l}57 \\
(14.2)\end{array}$ & $\begin{array}{l}80 \\
(20.0)\end{array}$ & $\begin{array}{l}74 \\
(18.5)\end{array}$ & $3.13^{\mathrm{a}}$ & 1.446 & $1.833^{*}$ \\
\hline 2 & $\begin{array}{l}\text { I can easily understand how my patient feel about } \\
\text { their health }(\mathrm{C} 2)\end{array}$ & $\begin{array}{l}109 \\
(27.2)\end{array}$ & $\begin{array}{l}150 \\
(37.5)\end{array}$ & $\begin{array}{l}64 \\
(16.0)\end{array}$ & $\begin{array}{l}56 \\
(14.0)\end{array}$ & $\begin{array}{l}21 \\
(5.2)\end{array}$ & $3.68^{\mathrm{a}}$ & 1.167 & $11.564^{\star}$ \\
\hline 3 & $\begin{array}{l}\text { I feel patients blame me for some of their problems } \\
\text { (C3) }\end{array}$ & $\begin{array}{l}69 \\
(17.2)\end{array}$ & $\begin{array}{l}77 \\
(19.2)\end{array}$ & $\begin{array}{l}83 \\
(20.7)\end{array}$ & $\begin{array}{l}67 \\
(16.7)\end{array}$ & $\begin{array}{l}104 \\
(26.0)\end{array}$ & $2.85^{\mathrm{da}}$ & 1.440 & $-2.084^{\star}$ \\
\hline 4 & $\begin{array}{l}\text { I deal very efficiently with the problems of my } \\
\text { patients (C4) }\end{array}$ & $\begin{array}{l}104 \\
(26.0)\end{array}$ & $\begin{array}{l}164 \\
(41.0)\end{array}$ & $\begin{array}{l}53 \\
(13.2)\end{array}$ & $\begin{array}{l}60 \\
(15.0)\end{array}$ & $\begin{array}{l}19 \\
(4.7)\end{array}$ & $3.69^{\mathrm{a}}$ & 1.151 & $11.906^{*}$ \\
\hline
\end{tabular}

N:B- W.M.S. = weighted mean score; agreed $\leq 3.00 \geq$ disadgreed. Average WMS = 3.00; SA = Strongly agreed; A = Agreed; $\mathrm{N}=\mathrm{Neutral} ; \mathrm{D}=$ disagree; $\mathrm{SD}=$ strongly disagreed. Source: Field survey, 2020. 
generalization where they are used in evaluating reliability [20] Mohsen and Reg (2011) and Kendall's W tests result were emotional exhaustion (0.671; 0.110), personal accomplishment $(0.699,0.142)$ and depersonalization $(0.636,0.050)$. In general term, the instrument used was internally consistent, however, not more than $11 \%, 14.2 \%$ and $5 \%$ of the respondents had uniform opinions about the element of each dimension. This may be due to divergence of disciplines across the health sector.

Table 2 shows that job burnout has three dimensions. Five (5) out of six (6) items used to capture emotional exhaustion variable (A1-A6) were statistically significant ( $\mathrm{t}$-value $\geq 1.96$ ) showing both the mean score and standard deviation. For "am emotionally disturbed by this work (2.67 \pm 1.45$)$; I feel scared occasionally when I get up in the morning and have to face another day on my job (2.51 $\pm 1.34)$; Working with people directly put too much pressure on me $(2.37 \pm$ 1.45); I find it easy to create a relaxed atmosphere and condition with my patients $(3.42 \pm 1.34)$; I personally feel energetic in my job $(3.31 \pm 1.38)$ ". The mean values for the first three (3) items had below 3.0 average score, and disagreed cumulatively whereas, the mean values for last two (2) items had above 3.0 average score, and agreed cumulatively.

For personal accomplishment, seven (7) items B1-B7 used were significant at $(\mathrm{T} \geq 1.69)$. In terms of mean and standard deviation scores, respondents agreed that "I have positive feeling that my work with people is influencing others" life (3.86 \pm 1.28$)$ "; "I feel I am working too hard on my job (3.21 \pm 1.33$)$ "; "I calmly deal with emotional problems in my work $(3.73 \pm 1.28)$ " whereas respondents cumulatively disagreed that "Working with people everyday trains me $(2.61 \pm$ 1.38)"; "I feel I treat some recipients as if they were impersonal 'object' ( $2.60 \pm$ $1.50)$ "; "I do not really care what happens to some patients ( $2.43 \pm 1.62)$ ", and "I have become more callous towards people since I took my job (2.47 \pm 1.57$)$ ".

Depersonalization was also capture using a 4-item C1-C4 construct. Three (3) of these four (4) items were collectively agreed among respondents and had the following mean and standard deviation scores. For "I feel burned out from my job $(3.13 \pm 1.45)$ "; "I can easily understand how my patient feel about their health $(3.68 \pm 1.17)$ "; and "I deal very efficiently with the problems of my patients $(3.69 \pm 1.15)$ " whereas, "I feel patients blame me for some of their problems $(2.85 \pm 1.44)$ " was disagreed generally.

\subsection{Element of Employee Satisfaction in the Nigerian Health Sector}

Table 3 presented distributions of respondents on items constituting employee satisfaction. Seven (7) of the ten (10) items used were statistically significant ( $\mathrm{T} \geq$ 1.96) and the average scores all conformed to agreement in opinions (WMS > 3.00). The mean and standard deviation were: I give full attention to patients to show care and concern (3.96 \pm 1.16$)$; My performance is enhanced by the resources made available for my daily work demands (3.68 \pm 1.15$)$; The number of 
patient I needed to attend to daily are too many for me to cope with given time constraint $(3.28 \pm 1.22)$; My response time to patients' issues is prompt anytime there is a case before me $(3.54 \pm 1.23)$; The number of patients I need to attend to daily are too many for me to cope with given the material resources needed for my task $(3.29 \pm 1.13)$; My interest to engage in private practice is not doubtful because of poor working conditions (3.18 \pm 1.28$)$; My complaints regarding job demands, heavy workloads and work demands are increasing $(3.23 \pm 1.27)$.

The instrument was tested for internal reliability and degree of concordance. Cronbach's alpha and Kendall's W tests result were 0.775 and 0.068 . In general terms, the instrument used was internally consistent, and about $6.8 \%$ of the respondents agreed with respect to choice of opinion responses to the ten (10) items.

Table 3. Table showing employee satisfaction.

\begin{tabular}{|c|c|c|c|c|c|c|c|c|c|}
\hline \multirow[t]{2}{*}{$S / N$} & \multirow[t]{2}{*}{ Employee satisfaction } & \multirow{2}{*}{$\begin{array}{l}\text { SA } \\
\text { F } \\
(\%)\end{array}$} & A & $\mathbf{N}$ & $\mathrm{D}$ & SD & \multicolumn{3}{|c|}{$\begin{array}{l}\text { Cronbach alpha }=0.775 \\
\text { Kendall's W } \\
\text { coefficient }=0.068^{\star}\end{array}$} \\
\hline & & & $\begin{array}{l}\mathrm{F} \\
(\%)\end{array}$ & $\begin{array}{l}\mathrm{F} \\
(\%)\end{array}$ & $\begin{array}{l}\mathrm{F} \\
(\%)\end{array}$ & $\begin{array}{l}\mathrm{F} \\
(\%)\end{array}$ & WMS & Std. De & t-value \\
\hline 1 & $\begin{array}{l}\text { I give full attention to patients to show care and } \\
\text { concern }\end{array}$ & $\begin{array}{l}155 \\
(38.7)\end{array}$ & $\begin{array}{l}148 \\
(37.0)\end{array}$ & $\begin{array}{l}51 \\
(12.7)\end{array}$ & $\begin{array}{l}17 \\
(4.2)\end{array}$ & $\begin{array}{l}29 \\
(7.2)\end{array}$ & $3.96^{\mathrm{a}}$ & 1.157 & $16.549^{*}$ \\
\hline 2 & $\begin{array}{l}\text { My performance is enhanced by the resources } \\
\text { made available for my daily work demands }\end{array}$ & $\begin{array}{l}98 \\
(24.5)\end{array}$ & $\begin{array}{l}170 \\
(42.5)\end{array}$ & $\begin{array}{l}65 \\
(16.2)\end{array}$ & $\begin{array}{l}40 \\
(10.0)\end{array}$ & $\begin{array}{l}27 \\
(6.7)\end{array}$ & $3.68^{\mathrm{a}}$ & 1.147 & $11.856^{*}$ \\
\hline 3 & $\begin{array}{l}\text { The number of patients I needed to attend to } \\
\text { daily are too many for me to cope with given } \\
\text { time constraint }\end{array}$ & $\begin{array}{l}79 \\
(19.7)\end{array}$ & $\begin{array}{l}104 \\
(26.0)\end{array}$ & $\begin{array}{l}96 \\
(24.0)\end{array}$ & $\begin{array}{l}93 \\
(23.2)\end{array}$ & $\begin{array}{l}28 \\
7.00\end{array}$ & $3.28^{\mathrm{a}}$ & 1.219 & $4.634^{*}$ \\
\hline 4 & $\begin{array}{l}\text { I always have challenges accomplishing my job } \\
\text { demands because of stress }\end{array}$ & $\begin{array}{l}58 \\
(14.5)\end{array}$ & $\begin{array}{l}102 \\
(25.5)\end{array}$ & $\begin{array}{l}58 \\
(14.5)\end{array}$ & $\begin{array}{l}147 \\
(36.8)\end{array}$ & $\begin{array}{l}35 \\
(8.7)\end{array}$ & $3.00^{\mathrm{da}}$ & 1.248 & $0.040^{\mathrm{NS}}$ \\
\hline 5 & $\begin{array}{l}\text { My response time to patients' issues is prompt } \\
\text { anytime there is a case before me }\end{array}$ & $\begin{array}{l}104 \\
(26.0)\end{array}$ & $\begin{array}{l}125 \\
(31.2)\end{array}$ & $\begin{array}{l}87 \\
(21.7)\end{array}$ & $\begin{array}{l}51 \\
(12.7)\end{array}$ & $\begin{array}{l}33 \\
(8.2)\end{array}$ & $3.54^{\mathrm{a}}$ & 1.234 & $8.754^{*}$ \\
\hline 6 & $\begin{array}{l}\text { My disposition towards work anytime I plan to } \\
\text { go to work not gratifying because of my work } \\
\text { environment }\end{array}$ & $\begin{array}{l}72 \\
(18.0)\end{array}$ & $\begin{array}{l}98 \\
(24.5)\end{array}$ & $\begin{array}{l}76 \\
(19.0)\end{array}$ & $\begin{array}{l}113 \\
(28.2)\end{array}$ & $\begin{array}{l}41 \\
(10.2)\end{array}$ & $3.12^{\mathrm{a}}$ & 1.284 & $1.831^{\mathrm{NS}}$ \\
\hline 7 & $\begin{array}{l}\text { The number of patients I need to attend to } \\
\text { daily are too many for me to cope with given } \\
\text { the material resources needed for my task }\end{array}$ & $\begin{array}{l}53 \\
(13.2)\end{array}$ & $\begin{array}{l}152 \\
(38.0)\end{array}$ & $\begin{array}{l}73 \\
(18.2)\end{array}$ & $\begin{array}{l}103 \\
(25.8)\end{array}$ & $\begin{array}{l}19 \\
(4.7)\end{array}$ & $3.29^{\mathrm{a}}$ & 1.129 & $5.181^{*}$ \\
\hline 8 & $\begin{array}{l}\text { My interest to engage in private practice is } \\
\text { undoubted because of poor working } \\
\text { conditions }\end{array}$ & $\begin{array}{l}77 \\
(19.2)\end{array}$ & $\begin{array}{l}91 \\
(22.7)\end{array}$ & $\begin{array}{l}102 \\
(25.5)\end{array}$ & $\begin{array}{l}85 \\
(21.2)\end{array}$ & $\begin{array}{l}45 \\
(11.2)\end{array}$ & $3.18^{\mathrm{a}}$ & 1.278 & $2.739^{*}$ \\
\hline 9 & $\begin{array}{l}\text { My complaints regarding job demands, heavy } \\
\text { workloads and work demands are increasing }\end{array}$ & $\begin{array}{l}74 \\
(18.5)\end{array}$ & $\begin{array}{l}119 \\
(29.7)\end{array}$ & $\begin{array}{l}68 \\
(17.0)\end{array}$ & $\begin{array}{l}101 \\
(25.2)\end{array}$ & $\begin{array}{l}38 \\
(9.50)\end{array}$ & $3.23^{\mathrm{a}}$ & 1.274 & $3.532^{*}$ \\
\hline 10 & $\begin{array}{l}\text { My organization is experiencing high employee } \\
\text { turnover }\end{array}$ & $\begin{array}{l}54 \\
(13.5)\end{array}$ & $\begin{array}{l}88 \\
(22.0)\end{array}$ & $\begin{array}{l}91 \\
(22.7)\end{array}$ & $\begin{array}{l}91 \\
(22.7)\end{array}$ & $\begin{array}{l}76 \\
(19.0)\end{array}$ & $2.88^{\mathrm{da}}$ & 1.318 & $-1.783^{\mathrm{NS}}$ \\
\hline
\end{tabular}

N:B- W.M.S. = weighted mean score; agreed $\leq 3.00 \geq$ disadgreed. Average WMS = 3.00; $\mathrm{SA}=$ Strongly agreed; A = Agreed; $\mathrm{N}=\mathrm{Neutral} ; \mathrm{D}=\mathrm{disagree} ; \mathrm{SD}=$ strongly disagreed. Source: Field survey, 2020. 


\subsection{Factorization of Dimension of Job Burnout}

The inter-items correlation matrix in Table 4 showed that items A1-A5; B1, B2, B4, B5, B6 and C2, C4 had weak correlation with one or more other variables representing emotional exhaustion, personal accomplishment and depersonalization and as such a multiple regression analysis can be carried out to answer the $\mathrm{H}_{01}$. However, item A5, A6; B3, C1, C3 are either mildly or strongly correlated with other items. This implies that item A5, A6, B3, C1, and C3 are independent of other items of emotional exhaustion, personal accomplishment and depersonalization. Items with correlated components of the three dimensions of job burnout were thereby subjected to principal component analysis to eliminate subtle nuances of collinearity. Congruently, I find it easy to create a relaxed atmosphere and condition with my patients; I personally feel energetic in my job; I feel I am working too hard on my job; I feel burned out from my job; and I feel patients blame me for some of their problems were considered as independent predictors in regression model and thus excluded from factor analysis.

Table 4. Showing Inter-items correlation coefficients for the three dimensions of job burnout. (a) Emotional exhaustion; (b) Personal accomplishment; (c) Depersonalization.

(a)

\begin{tabular}{cccccc}
\hline & A1 & A2 & A3 & A4 & A5* \\
\hline A2 & 0.702 & & & & \\
A3 & 0.411 & 0.590 & & & \\
A4 & 0.616 & 0.651 & 0.433 & & \\
A5* & 0.172 & 0.144 & 0.168 & 0.220 & \\
A6 $^{*}$ & -0.197 & -0.200 & -0.181 & 0.028 & 0.171 \\
\hline
\end{tabular}

(b)

\begin{tabular}{ccccccc}
\hline & B1 & B2* & B3* & B4 & B5 & B6 \\
\hline B2* & 0.021 & & & & & \\
B3* & 0.324 & 0.246 & & & & \\
B4 & 0.508 & -0.120 & 0.341 & & & \\
B5 & 0.474 & -0.196 & 0.269 & 0.752 & & \\
B6 & 0.531 & -0.186 & 0.188 & 0.624 & 0.810 & \\
B7 & -0.044 & 0.401 & 0.260 & -0.047 & -0.118 & -0.146 \\
\hline
\end{tabular}

(c)

\begin{tabular}{cccc}
\hline & $\mathrm{C1}^{*}$ & $\mathrm{C} 2$ & $\mathrm{C}^{*}$ \\
\hline $\mathrm{C} 2$ & 0.032 & & \\
$\mathrm{C} 3^{*}$ & 0.285 & -0.117 & \\
$\mathrm{C} 4$ & 0.082 & 0.539 & -0.009 \\
\hline
\end{tabular}

* implies an item has low correlation with other items. 
As a result, four (4), five (5), and two (2) items in Table 4 representing emotional exhaustion, personal accomplishment and depersonalization respectively were subjected to principle component analysis. Table 5 shows that The Kaiser-Meyer-Olkin Measure of Sampling Adequacy were 0.773, 0.719, 0.500 indicating that $77.3 \%, 71.9 \%$ and $50.0 \%$ of variance in emotional exhaustion, personal accomplishment and depersonalization variables respectively might be caused by underlying factors. Similarly, significant at $\mathrm{P}<0.01$, Bartlett's test of sphericity tests for emotional exhaustion (697.393); personal accomplishment (942.966); and depersonalization (136.612) indicated that the variables of job burnout dimensions were related and therefore suitable for structure detection. The average variance extracted (AVE) does not go below the recommended Eigen value of 0.50 (Hair et al., 1998). This is the amount of variations in the four (4), four (4) and two (2) items for the three job burnout dimensions respectively depicting convergent validity of the study structure.

\subsection{Effects of Job Burnout on Employee Satisfaction among Selected Health Service Employee in Southwestern Nigeria}

Ho: job burnout does not influence employee's satisfaction.

$\mathrm{H}_{1}$ : job burnout has influence on employee's satisfaction.

Factor analysis extracted one (1), two (2), and one (1) major principal components each to explain nearly $68 \%, 78 \%$ and $77 \%$ of the variability in the original four (4), four (4) and two (2) variables of emotional exhaustion, personal accomplishment and depersonalization. These components were strongly correlated with the following principal components: For emotional exhaustion, component 1 representing factor 1 was associated with 4 items - A1 (0.838), A2 (0.903), A3 (0.719) and A4 (0.825). For personal accomplishment: component 1 representing factor 2 was associated with four (4) items - B1 (0.735), B4 (0.858), B5 (0.899), B6 (0.872) and component 2 representing factor 3 was associated with two (2) items - B2 (0.837), B7 (0.826). Similarly, for depersonalization component 1 representing factor 4 was associated with two (2) items - C2 (0.877) and C4 (0.877). These were then compressed into four (4) predictors: Occasional fear of working (factor score 1); positive feeling of influencing others' life at work (factor score 2); carefree attitude at work toward patients (factor score 3); and over-concerns for patient's health (factor score 4). The four estimated factor scores were used in lieu of the predictors' values in regression analysis.

Regression analysis tested the effects of job burnout on employee satisfaction. There were 3 indicators: demographic factors to control for individual and professional biases; the four (4) factor estimates from factor analysis and independents predictors to account for the job burnout dimensions, these were regressed against employee satisfaction. The outputs were given in Table 6 .

In the regression results, R-square score depicted that the three (3) dimensions of job burnout respectively included in the model, that is, emotional exhaustion, personal accomplishment, depersonalization and demographic va- 
riables accounted for about $23 \%, 37 \%, 44 \%$ and $45 \%$ of variations in employee satisfaction respectively in the health sector of Nigeria. A Durbin-Watson statistic of 2.189 was obtained, which indicated that the model predictors are non-collinear. The significant F-tests $(58.870,46.476,30.075,24.242, \mathrm{P}<0.01)$ for the three dimensions of job burnout revealed that model is fit for this analysis and $\mathrm{H}_{01}$ cannot be rejected. Thus, it is affirmed that job burnout significantly affects employee satisfaction in the health sector of Nigeria.

Table 5. KMO and Bartlett's Test of sphericity.

\begin{tabular}{|c|c|c|c|c|}
\hline & & $\begin{array}{l}\text { Emotional } \\
\text { Exhaustion }\end{array}$ & $\begin{array}{l}\text { Personal } \\
\text { Accomplishment }\end{array}$ & Depersonalization \\
\hline \multicolumn{2}{|c|}{$\begin{array}{l}\text { Kaiser-Meyer-Olkin } \\
\text { Measure of Sampling Adequacy. }\end{array}$} & 0.773 & 0.719 & 0.500 \\
\hline \multirow{3}{*}{$\begin{array}{l}\text { Bartlett's Test } \\
\text { of Sphericity }\end{array}$} & Approx. Chi-Square & 1016.229 & 942.966 & 136.612 \\
\hline & Df & 15 & 10 & 1 \\
\hline & Sig. & 0.000 & 0.000 & 0.000 \\
\hline
\end{tabular}

Df = degree of freedom; Source: Author's analysis, 2020.

Table 6. OLS Regression showing impact of job burnout on employee satisfaction.

\begin{tabular}{|c|c|c|c|c|c|c|}
\hline \multirow[t]{2}{*}{ Employee satisfaction } & \multicolumn{2}{|c|}{$\begin{array}{l}\text { Standardized } \\
\text { Coefficients }\end{array}$} & \multicolumn{4}{|c|}{ Durbin-Watson $=2.189$} \\
\hline & Beta & Std. Error & $\mathrm{R}^{2}$ & F-value & T-value & Sig. \\
\hline Emotional Exhaustion & & & 0.229 & 58.870 & & 0.000 \\
\hline $\begin{array}{l}\text { Ease of creating a relaxed atmosphere } \\
\text { with patients }\end{array}$ & 0.050 & 0.023 & & & 1.176 & 0.240 \\
\hline $\begin{array}{l}\text { Occasional fear among employee due to } \\
\text { work }\end{array}$ & $-0.165^{\star}$ & 0.041 & & & -2.808 & 0.005 \\
\hline Personal Accomplishment & & & 0.371 & 46.476 & & 0.000 \\
\hline I feel I am working too hard on my job & 0.058 & 0.025 & & & 1.251 & 0.212 \\
\hline $\begin{array}{l}\text { Positive feeling of influencing others' life } \\
\text { at work }\end{array}$ & $0.210^{*}$ & 0.038 & & & 3.879 & 0.000 \\
\hline Carefree attitude at work toward patients & $0.251^{*}$ & 0.031 & & & 5.787 & 0.000 \\
\hline Depersonalization & & & 0.438 & 34.075 & & 0.000 \\
\hline I feel burned out from my job & $-0.158^{\star}$ & 0.025 & & & -3.113 & 0.002 \\
\hline $\begin{array}{l}\text { I feel patients blame me for some of their } \\
\text { problems }\end{array}$ & $-0.186^{\star}$ & 0.023 & & & -3.993 & 0.000 \\
\hline over-concerns for patient's health & $-0.151^{\star}$ & 0.032 & & & -3.390 & 0.001 \\
\hline Demographic characteristics & & & 0.449 & 24.242 & & 0.000 \\
\hline Gender & $-0.076^{\star * x}$ & 0.058 & & & -1.869 & 0.062 \\
\hline Age & -0.028 & 0.070 & & & -0.538 & 0.591 \\
\hline Academic Qualification & 0.053 & 0.035 & & & 1.073 & 0.284 \\
\hline Year of Service & -0.042 & 0.031 & & & -0.796 & 0.427 \\
\hline Specialty & 0.003 & 0.030 & & & 0.068 & 0.946 \\
\hline (Constant) & 2.805 & 0.213 & & & 13.150 & 0.000 \\
\hline
\end{tabular}

Source: author's analysis, 2020. 
Examining each and every job burnout dimensions and demographic features of respondents in Table 6 , only coefficient of gender $(\beta=0.076, \mathrm{P}<0.1)$ out of all the control variables, had a significant influence on employee satisfaction but negative. This implies that $1.0 \%$ increase in the number of men in the health sector will likely lead to $7.6 \%$ decline in employee satisfaction. Going by this, employee gender also plays a role in job satisfaction.

Lending credence to marginal relationship among job burnout variables, only elements of personal achievement had significantly positive correlation with employee satisfaction. These were "positive feeling of influencing others' life at work $(\beta=0.210, \mathrm{P}<0.01)$; and carefree attitude at work toward patients $(\beta=$ $-0.251, \mathrm{P}<0.01)$. On the other hand, elements of emotional exhaustion and depersonalization - occasional fear among employee due to work $(\beta=-0.165, \mathrm{P}<$ 0.01); I feel burned out from my job $(\beta=-0.158, \mathrm{P}<0.01)$; I feel patients blame me for some of their problems $(\beta=-0.186, \mathrm{P}<0.01)$; and over-concerns for $\mathrm{pa}-$ tient's health $(\beta=-0.151, \mathrm{P}<0.01)$ " respectively had significant inverse relationship with employee satisfaction.

In all, if the rate at which employees feel positive of their influence on others' life at work and as well, employee show carefree attitude toward patients rise by $1.0 \%$ each, the likelihood that employee satisfaction will improve are $21.0 \%$ and $25.1 \%$ respectively. On the other hand, if there is $1.0 \%$ increase in the occasional fear due to work experienced by employees; employee feeling of job burnout; employees feel being blamed by patients for some of their problems; and employee have over-concerns for patient's health, corresponding, there would be about $16.5 \%, 15.8 \%, 18.6 \%$, and $15.1 \%$ likely declines in employee satisfaction in the Nigerian health sector.

\section{Conclusion and Recommendation}

The study has examined the effects of job burnout on employees' satisfaction in the health service sector of Southwestern, Nigeria and concluded that element of personal achievement has a significant positive correlation with employee satisfaction which is in agreement with the work of [2] Tsai et al. (2020). This implies that employees should be given liberty to express his/her care altitude towards their patient, thereby giving employee a positive feeling of influencing other peoples' life. Also, element of emotional exhaustion and depersonalisation had significant inverse relationship with employee satisfaction [13] Wafaa (2019); [17] Swartz \& Potgieter (2017) by implication employer can give sufficient motivation, increase organisational support and streamline the job demand in order to reduce the level of burnout among employees' in health service sector and a continuous policy should be taken to mitigate against the elements of job burnout.

\section{Conflicts of Interest}

The authors declare no conflicts of interest regarding the publication of this paper. 


\section{References}

[1] Ubochi, N.E., Ehwarieme, T.A., Anarado, A.N. and Oyibocha, E.O. (2019) Building a Strong and Sustainable Health Care System in Nigeria: The Role of the Nurse. International Journal of Nursing and Midwifery, 11, 61-67. https://doi.org/10.5897/IJNM2019.0374

[2] Tsai, J., Jones, N., Klee, A. and Deegan, D. (2020) Job Burnout among Mental Health Staff at a Veteran's Affairs Psychology Rehabilitation Centre. Community Mental Health Journal, 56, 294-297. https://doi.org/10.1007/s10597-019-00487-5

[3] Elham, A., Steven, W.B. and Cem, T. (2019) Workplace Bullying, Psychological Distress, Resilience, Mindfulness, and Emotional Exhaustion. The Service Industries Journal, 39, 1-25.

[4] Bazmi, E., Alipour, A., Yasamy, M.T., Kheradmand, A., Salehpour, S., Khodakarim, S. and Soori, H. (2019) Job Burnout and Related Factors among Health Sectors Employees. Iranian Journal of Psychiatry, 14, 309-316. https://doi.org/10.18502/ijps.v14i4.1982

[5] Luna-Arocas, R. and Camps, J. (2008) A Model of High-Performance Work Practices and Turnover Intentions. Journal of Personnel Review, 37, 26-64. https://doi.org/10.1108/00483480810839950

[6] Karabay, M.E., Tezergil, S.A. and Kose, A. (2014) Does Motivation Mediate the Job Performance and Burnout? Evidence from Turkish Banking Sector. American International Journal of Social Science, 3, 98-108.

[7] Maslash, C. and Jackson, S.E. (1981) The Measurement of Experienced Burnout. Journal of Occupational Behavior, 2, 99-113. https://doi.org/10.1002/job.4030020205

[8] Wright, T.A. and Bonett, D.G. (1997) The Role of Pleasantness and Activation-Based Well-Being in Performance Prediction. Journal of Occupational Health Psychology, 2, 212-219. https://doi.org/10.1037/1076-8998.2.3.212

[9] Meyer, J.P., Stanly, D.J., Herscovitch, L. and Topolnytsky, L. (2002) Affective, Continuance, and Normative Commitment to the Organisation: A Meta-Analysis of Antecedents, Correlates, and Consequences. Journal of Vocational Behavior, 61, 20-52. https://doi.org/10.1006/jvbe.2001.1842

[10] Franke, G.R. and Park, J.E. (2006) Salesperson Adaptive Selling Behavior and Customer Orientation: A Meta-Analysis. Journal of Marketing Research, 43, 693-702. https://doi.org/10.1509/jmkr.43.4.693

[11] Riggle, R., Edmondson, D.R. and Hansen, J.D. (2009) A Meta-Analysis of the Relationship between Perceived Organisational Support and Job Outcomes. Journal of Business Research, 62, 1027-1030. https://doi.org/10.1016/j.jbusres.2008.05.003

[12] Koster, F., Grip, A. and Fouarge, D. (2011) Does Perceived Support in Employee Development Affect Personnel Turnover? The International Journal of Human Resource Management, 22, 2403-2418. https://doi.org/10.1080/09585192.2011.584404

[13] Wafaa, M.A. (2019) The Impact of Job Burnout on the Performance of Staff Member at King Abdul-Aziz University. International Journal of Business and Social Science, 10, 126-136. https://doi.org/10.30845/ijbss.v10n4p15

[14] Sugumaran, B., Ahdullah, M.S. and Manaf, A.H. (2016) The Influence of Dimensions of Job Burnout on Employees' Commitment: A Perspective of Malaysia. Saudi Journal of Business and Management Studies, 1, 169-178.

[15] Lizano, E.L. (2015) Examining the Impact of Job Burnout on the Health and Well-Being of Human Service Workers: A Systematic Review and Synthesis, Hu- 
man Service Organisations. Journal of Management Leadership and Governance, 39, 376-378. https://doi.org/10.1080/23303131.2015.1014122

[16] Al-Adwan, F.E. and Al-Khayat, M. (2017) Psychological Burnout in Early Childhood Teachers: Levels and Reasons. International Education Studies, 10, 179-189. https://doi.org/10.5539/ies.v10n1p179

[17] Swartz, L. and Potgieter, C.A. (2017) Work Stress, Burnout and Organisation Politics: Perceptions and Experience of Senior Managers in the South African Government Sector. Review of Public Administration and Management, 5, 1-8. https://doi.org/10.4172/2315-7844.1000200

[18] Adebayo, O., Segun-Adeniran, C.D., Fagbohun, M.O. and Osayande, O. (2018) Investigating Occupational Burnout in Library Personnel. Library Philosophy and Practice (e-journal), 1770.

[19] NPC (2006) Annual Abstract of Statistics, National Population Commission. http://nigerianstat.gov.ng/annual_reports/Chapter\%202.ZIP

[20] Mohsen, T. and Reg, D. (2011) Making Sense of Cronbach's Alpha. International Journal of Medical Education, 2, 53-55. 